\title{
Analysis of Equity Based Mutual Funds in India
}

\author{
Sahil Jain \\ (Department of Mathematics, Indian Institute of Technology Roorkee, INDIA)
}

\begin{abstract}
The last decade has seen a tremendous growth in the mutual fund industry. As per the latest data the assets under management in this industry is more than Rs 6.8 thousand billion. Today the Indian market is flooded with more than a thousand mutual fund schemes, promising better returns than others. In this paper an attempt has been made to analyze the performance of equity based mutual funds. A total of 45 schemes offered by 2 private sector companies and 2 public sector companies, have been studied over the period April 1997 to April 2012 (15 years). The analysis has been made using the risk-return relationship and CapitalAssetPricingModel (CAPM).

The overall analysis finds that HDFC and ICICI have been the best performers, UTI an average performer and LIC the worst performer which gave below-expected returns on the risk-return relationship.

Keywords: Comparison, India, Mutual funds, Performance and risk-return,
\end{abstract}

\section{Introduction}

A mutual fund is a professionally managed type of collective investment scheme that pools money from many investors and invests it in stocks, bonds, short-term money market instruments and other securities. There are many reasons why investors prefer mutual funds. Buying shares directly from the market is one way of investing. But this requires spending time to find out the performance of the company whose share is being purchased, understanding the future business prospects of the company, finding out the track record of the promoters and the dividend, bonus issue history of the company etc. An informed investor needs to do research before investing. However, many investors find it cumbersome and time consuming to pore over so much of information, get access to so much of details before investing in the shares. Investors therefore prefer the mutual fund route. They invest in a mutual fund scheme which in turn takes the responsibility of investing in stocks and shares after due analysis and research. The investor need not bother with researching hundreds of stocks. It leaves it to the mutual fund and its professional fund management team.

The history of Mutual Funds in India can be dated back to 1963, when UTI was established, by an act of Parliament. As on $30^{\text {th }}$ April 2012, the total number of mutual fund schemes in India are 1292, which is worth Rs 6,80,154 crores (also called Asset under management). In this context it becomes pertinent to study the pattern and behavior of the Mutual fund schemes, to which the common man is still unaware of. The risk-return relationship is perhaps one of the best way to analyze the performance of a mutual fund.

\section{Objectives Of The Study}

The last decade has seen a tremendous growth in the mutual fund industry. As per the latest data the assets under management in this industry is more than Rs 6.8 thousand billion. Today the Indian market is flooded with more than a thousand mutual fund schemes, promising better returns than others. However for a common man, it becomes a challenge to select the best portfolio to invest. With this, it becomes pertinent to analyze the performance of these assets under management. An attempt has been made to study the performance ofequity-basedmutualfundsinIndia.

The objective of the study is to bring out a comparison between the performance of, equity-based mutual funds of public and private sector, in India. The basic tool would be the Capital Asset pricing Model (CAPM). Using CAPM one can calculate the expected rate of return for a portfolio, given its risk.So, in this paper the first task is to calculate the risk associated with a mutual fund. This is denoted by beta in CAPM. A collective data for period of 15 years has been considered to calculate beta. Once we calculate beta, we can easily calculate the expected rate of return from a mutual fund. The analysis is based on the risk-return relationship of the mutual fund. The analysis finds that, the private sector mutual funds, have outperformed the public sector ones.

\section{Review Of Literature}

Sathya Swaroop Debashish (2009) measured the performance of the equity based mutual funds in India. 23 schemes were studied over a period of April 1996 to March 2009 (13 years). The analysis was done on the basis of mean return, beta risk, coefficient of determination, sharp ratio, Treynor ratio and Jensen alpha. The first analysis has been done on the basis of returns, followed by a comparison between market returns and the return on schemes. It was concluded that UTI mutual fund schemes and Franklin Templeton schemes have performed 
excellently in public and private sectors respectively.Further, on the basis of the parameters like Sharpe ratio, Deutsche, Franklin Templeton, Prudential ICICI (in private sector) and SBI and UTI (in public sector) mutual funds schemes have out-performed the market portfolio with positive values. However, the overall analysis finds Franklin Templeton and UTI being the best performers, and Birla SunLife, HDFC and LIC mutual funds showing poor below-average performance when measured against the risk-return relationship models and measures.

Amporn Soongswang (2009) studied 138 open ended equity mutual funds managed by 17 asset management companies in Thailand during the period 2002-2007. When the mutual funds were measured using Treynor ratio, Sharp ratio and Jensen's alpha, showed that performance of Thai open ended mutual funds significantlyoutperformthemarket. However, by using the Data Envelopment analysis (DEA) technique, the results suggested that for 3 month time period of investment only, the open ended equity mutual fund significantly outperform the market.

\section{Data And Methodology}

The period of study is 1997- 2012. A total of 45 equity based mutual fund schemes have been considered. Out of 45, 20 belong to the public sector companies namely LIC and UTI, while the rest belong to the private sector, HDFC and ICICI. For calculation of the risk, the study has used the daily closing Net Asset Values (NAV) of the mutual funds along with daily closing price of the benchmark stock index -NIFTY and SENSEX. The main idea of the study is to calculate the expected return from a scheme (which is commensurate with the risk), and then comparing it with its actual rate of return over the given time period. To find how risky a scheme is, we calculate its risk coefficient beta, as defined in the CAPM. We define the following terms for this:

$\mathrm{R}_{\mathrm{i}}$ : Daily growth rate of Mutual Fund

$$
R_{i}=\frac{N A V_{i}-N A V_{i-1}}{N A V_{i-1}}
$$

where $\mathrm{NAV}_{\mathrm{i}}$ denotes the net asset value of a scheme at time $\mathrm{i}$.

$\overline{R_{i}}$ : Mean daily growth rate of a scheme.

$$
\overline{R_{i}}=\sum_{i=1}^{n} \frac{R_{i}}{n}
$$

Similarly for market index, which is either NIFTY or SENSEX, we define:

$\mathrm{R}_{\mathrm{mi}}$ : Daily Growth rate of the Market index

$\overline{R_{m}}$ : Mean daily growth rate of the market index

$$
R_{m i}=\frac{I_{i}-I_{i-1}}{I_{i-1}}
$$

$$
\overline{R_{m}}=\sum_{i=1}^{n} \frac{R_{m i}}{n}
$$

Where $R_{m i}$ is the growth rate of the market index and $n$ is the number of days for which it has been studied.

\subsection{Risk free Rate of Return $\left(\mathbf{R}_{\mathrm{f}}\right)$}

In this study, $\mathrm{R}_{\mathrm{f}}$ is taken as the fixed deposit rate in the nationalized banks.

From the Capital Asset Pricing Model, the beta of an asset, which measures the risk of an asset, is calculated by formula:

$$
\beta=\frac{\sigma_{m, i}}{\sigma_{m}{ }^{2}}=\frac{\operatorname{Cov}\left(R_{i}, R_{m}\right)}{\operatorname{Var}\left(R_{m}\right)}=\frac{\sum\left[\left(R_{i}-\overline{R_{i}}\right)\left(R_{m i}-\overline{R_{m}}\right)\right]}{\sum\left[\left(R_{m i}-\overline{R_{m}}\right)^{2}\right]}
$$

\subsection{Expected Rate of Return $\left(E\left[R_{i}\right]\right)$}

After calculating the risk parameter (beta) of an asset, and the annual growth rate of the market index, we calculate the expected rate of return of the mutual fund scheme. The formula is derived from the CAPM :

$$
E\left[R_{i}\right]=R_{f}+\beta\left(E\left[R_{m}\right]-R_{f}\right)
$$


Analysis of Equity Based Mutual Funds in India

\section{Emperical Findings}

Table 1: Performance of schemes on the basis of their Risk-Return Parameters

\begin{tabular}{|c|c|c|c|c|c|c|c|c|}
\hline & S.No. & Mutual Fund & $\begin{array}{l}\text { Risk } \\
\text { Factor } \\
\text { (Beta) }\end{array}$ & $\begin{array}{c}\text { Annual } \\
\text { Return on } \\
\text { market }\end{array}$ & $\begin{array}{l}\text { Expected } \\
\text { Rate of } \\
\text { return }\end{array}$ & $\begin{array}{l}\text { Actual } \\
\text { Rate of } \\
\text { Return }\end{array}$ & Difference & Performance \\
\hline \multirow{9}{*}{ HDFC } & 1 & Capital Builder & 0.69 & 18.77 & 15.4313 & 26 & 10.5687 & Overperformed \\
\hline & 2 & Growth Fund & 0.79 & 18.77 & 16.5083 & 26.52 & 10.0117 & Overperformed \\
\hline & 3 & Long Term Equity & 0.65 & 9.32 & 8.858 & 7.53 & -1.328 & Average \\
\hline & 4 & Sensex Plan & 0.95 & 18.32 & 17.804 & 30.47 & 12.666 & Overperformed \\
\hline & 5 & Childeren Gift Fund & 0.36 & 18.35 & 11.726 & 14.88 & 3.154 & Overperformed \\
\hline & 6 & Income Fund & 0.02 & 19.22 & 8.2244 & 6.62 & -1.6044 & Average \\
\hline & 7 & Mid-Cap opportunity fund & 0.56 & 4.16 & 5.8496 & 11.08 & 5.2304 & Overperformed \\
\hline & 8 & Nifty Fund & 0.91 & 18.77 & 17.8007 & 16.85 & -0.9507 & Average \\
\hline & 9 & Sensex Plus & 0.86 & 18.32 & 16.8752 & 21.04 & 4.1648 & Overperformed \\
\hline \multirow{25}{*}{ ICICI } & 10 & Dynamic Plan & 0.75 & 20.14 & 17.105 & 27.52 & 10.415 & Overperformed \\
\hline & 11 & Banking and Financial & 0.93 & 5.74 & 5.8982 & 16.69 & 10.7918 & Overperformed \\
\hline & 12 & $\begin{array}{l}\text { Dynamic Plan -Institutional } \\
\text { Option }\end{array}$ & 0.72 & 5.33 & 6.0776 & 10.31 & 4.2324 & Overperformed \\
\hline & 13 & $\begin{array}{c}\text { Equity \& Derivatives Fund - } \\
\text { Wealth Optimiser - Regular } \\
\text { Growth }\end{array}$ & 0.57 & 5.51 & 6.5807 & 7.89 & 1.3093 & Overperformed \\
\hline & 14 & $\begin{array}{l}\text { Equity Opportunities Fund - } \\
\text { Inst. Growth }\end{array}$ & 0.72 & 11.13 & 10.2536 & 6.4 & -3.8536 & Underperformed \\
\hline & 15 & $\begin{array}{l}\text { Equity Opportunities Fund - } \\
\text { Retail Growth }\end{array}$ & 0.72 & 11.13 & 10.2536 & 5.38 & -4.8736 & Underperformed \\
\hline & 16 & $\begin{array}{l}\text { Focused Bluechip Equity } \\
\text { Fund - Inst. Growth }\end{array}$ & 0.86 & 1.79 & 2.6594 & 14.26 & 11.6006 & Overperformed \\
\hline & 17 & $\begin{array}{l}\text { Focused Bluechip Equity } \\
\text { Fund - Retail Growth }\end{array}$ & 0.85 & 1.79 & 2.7215 & 13.31 & 10.5885 & Overperformed \\
\hline & 18 & $\begin{array}{l}\text { Indo Asia Equity Fund - Inst } \\
\text { Growth }\end{array}$ & 0.61 & 0.36 & 3.3396 & 1.88 & -1.4596 & Average \\
\hline & 19 & $\begin{array}{l}\text { Infrastructure Fund - Inst. } \\
\text { Option - I - Growth }\end{array}$ & 0.88 & 5.37 & 5.6856 & 6.72 & 1.0344 & Overperformed \\
\hline & 20 & $\begin{array}{l}\text { MidCap Fund - Institutional } \\
\text { Option - I }\end{array}$ & 0.73 & 6.95 & 7.2335 & 4.42 & -2.8135 & Underperformed \\
\hline & 21 & R.I.G.H.T Fund Growth & 0.58 & 2.33 & 4.7114 & 12.18 & 7.4686 & Overperformed \\
\hline & 22 & $\begin{array}{l}\text { Services Industries Fund - } \\
\text { Growth Option }\end{array}$ & 0.82 & 10.67 & 10.1894 & 8.14 & -2.0494 & Underperformed \\
\hline & 23 & $\begin{array}{c}\text { Discovery } \\
\text { Fund(institutional) }\end{array}$ & 0.68 & 8.61 & 8.4148 & 14.14 & 5.7252 & Overperformed \\
\hline & 24 & Discovery Fund(G) & 0.69 & 16.73 & 14.0237 & 22.93 & 8.9063 & Overperformed \\
\hline & 25 & Prudential FMCG (G) & 0.51 & 12.42 & 10.2542 & 18.26 & 8.0058 & Overperformed \\
\hline & 26 & Nifty Growth & 0.92 & 18.92 & 18.0464 & 12.2 & -5.8464 & Underperformed \\
\hline & 27 & Top 100 Fund & 0.83 & -3.96 & -1.9268 & -6.86 & -4.9332 & Underperformed \\
\hline & 28 & Equity fund (G) & 0.93 & 12.59 & 12.2687 & 6.67 & -5.5987 & Underperformed \\
\hline & 29 & Tax Plan (G) & 0.85 & 12.85 & 12.1225 & 8.09 & -4.0325 & Underperformed \\
\hline & 30 & Opportunities Fund(G) & 0.91 & 13.98 & 13.4418 & 7.76 & -5.6818 & Underperformed \\
\hline & 31 & Sensex Plan (G) & 0.94 & 19.49 & 18.8006 & 13.26 & -5.5406 & Underperformed \\
\hline & 32 & India Vision Fund (G) & 0.85 & 5.43 & 5.8155 & -4.09 & -9.9055 & Underperformed \\
\hline & 33 & $\begin{array}{l}\text { Systematic Asset Allocation } \\
\text { Fund }(\mathrm{G})\end{array}$ & 0.4 & 0.93 & 5.172 & -1.67 & -6.842 & Underperformed \\
\hline & 34 & Sensex Advantage- Growth & 0.85 & 22.33 & 20.1805 & 14.36 & -5.8205 & Underperformed \\
\hline \multirow{11}{*}{ UTI } & 35 & NIFTY INDEX Fund & 0.98 & 14.02 & 13.8996 & 13.65 & -0.2496 & Average \\
\hline & 36 & Contra Fund & 0.78 & 4.98 & 5.6444 & 4.83 & -0.8144 & Average \\
\hline & 37 & Leadership Equity Fund & 0.87 & 4.96 & 5.3552 & 2.81 & -2.5452 & Underperformed \\
\hline & 38 & Long Term Advantage fund & 0.79 & 4.96 & 5.5984 & 2.86 & -2.7384 & Underperformed \\
\hline & 39 & Wealth Builder fund Series & 0.63 & 18.23 & 14.4449 & 25.06 & 10.6151 & Overperformed \\
\hline & 40 & Wealth Builder fund & 0.79 & 4.85 & 5.5115 & 8.37 & 2.8585 & Overperformed \\
\hline & 41 & Banking Sector fund & 1.02 & 4.98 & 4.9196 & 14 & 9.0804 & Overperformed \\
\hline & 42 & MASTER INDEX Fund & 0.99 & 13.49 & 13.4351 & 13.37 & -0.0651 & Average \\
\hline & 43 & UTI Top 100 & 0.83 & 5.24 & 5.7092 & 6.43 & 0.7208 & Average \\
\hline & 44 & Equity Tax Savings plan & 0.79 & 4.96 & 5.5984 & 4.45 & -1.1484 & Average \\
\hline & 45 & Equity Fund & 0.69 & 4.85 & 5.8265 & 11.45 & 5.6235 & Overperformed \\
\hline
\end{tabular}

\subsection{Returns}

Using equation (5) we calculate the beta value of a scheme which is listed in the third column of the table. A beta value of greater than 1 implies that the asset is more risky than market, and vice-versa. The period of study need not be same for all the mutual fund schemes, because the date of inception for all of them is different. So the fourth column depicts the annual rate of growth of market index, which is either SENSEX or NIFTY, for the aforesaid period. Now, using the formula in equation (6), we calculate the expected rate of return for the particular mutual fund scheme which is commensurate with its risk.The next column 
depicts the actual rate of return for the asset. Now the difference between the expected and actual rate of returns would lead us to the conclusion. If the difference is positive i.e. if the actual rate of return is greater than the expected return, the asset lies above the Security market line and vice-versa. Consequently, we say that the mutual fund scheme has over performed, and vice-versa.

However if the aforesaid difference is within the range of $2 \%$, it implies that the scheme is very close to the security market line and classified as averagely performed.

Table 2: Comparison between Public and private sector companies.

\begin{tabular}{|l|l|l|l|l|l|}
\hline & Company & Schemes & $\begin{array}{l}\text { Over- } \\
\text { performed }\end{array}$ & $\begin{array}{l}\text { Under- } \\
\text { performed }\end{array}$ & Average \\
\hline \multirow{2}{*}{ Private } & HDFC & 9 & 6 & 0 & 3 \\
\cline { 2 - 6 } & ICICI & 16 & 11 & 4 & 1 \\
\hline \multirow{2}{*}{ Public } & LIC & 9 & 0 & 9 & 0 \\
\cline { 2 - 6 } & UTI & 11 & 4 & 2 & 5 \\
\hline
\end{tabular}

Out of 45 mutual fund schemes analyzed, 25 belong to the private sector companies, while 20 belong to the public sector companies. The percentage of schemes which have over-performed is $67 \%, 69 \%, 36 \%$ and 0 , for HDFC, ICICI, UTI and LIC respectively. In other words, $68 \%$ of the private sector schemes, and $20 \%$ of the public sector schemes have over-performed.

From a different perspective $16 \%$ of the private schemes and $55 \%$ of the public sector schemes have underperformed.

\subsection{Systematic Risk (Beta)}

In the Capital Asset Pricing Model, the risk of any asset is measured by calculating its beta ( $\beta$ ). It measures howriskyanassetis, withrespecttothemarket.If beta of a scheme is greater than unity it implies that it's riskier than themarketindexandvice-versa.In this analysis of 45 schemes, there's just one scheme whose beta is greater one, which is Banking Sector fund of UTI. Despite its high risk factor, it has over performed by a huge margin of 9\%.Intherangofbeta(.8-1.0), therearetotal21mutualfundschemesoutof45.

This shows that nearly half of them are almost as risky as the Stock market. Among these 21 schemes, the contribution of HDFC, ICICI, LIC, and UTI are 3,5,8 and 5 respectively. In terms of individual percentage, these are $33 \%, 31 \%, 89 \%$ and $45 \%$ respectively.

\section{Conclusions}

The study has investigated the performance of equity based mutual fund schemes in India, using CAPM. In the long run, private sector companies have performed far better than the public sector ones. While HDFC and ICICI have been the best performers, LIC has been the worst. Among all the 9 mutual fund schemes of LIC there's not a single scheme which has over-performed. Whereas on the other hand 11 out of 16 schemes ofICICIand6utof9schemesofHDFChaveover-performed.UTI has been an average performer, since majority of its schemes have given the returns as expected. While 5 out of 11 schemes of UTI have performed average, 4 haveover-performed. The results clearly indicate that over the period of last 15 years, private sector mutual fund companies (HDFC and ICICI) have outperformed the public sector ones (LIC and UTI). Beta (risk) analysis shows that while HDFC and ICICI mutual funds have been least risky, LIC is the most risky. 8 out of 9 schemes $(89 \%)$ of LIC had beta value greater than .80 . This has been one of the reasons behind the poor performance of LIC. The overall analysis finds that the private sector mutual fund schemes have been less risky and more rewarding as compared to the public sector ones.

\section{Websites:}

\section{References}

$\begin{array}{ll}\text { [1] } & \text { http://in.finance.yahoo.com/q/hp?s=SENSEX.BO } \\ \text { [2] } & \text { http://in.finance.yahoo.com/q/hp?s=\%5ENSEI } \\ \text { [3] } & \text { http://www.amfiindia.com/AUM_CatAgewiseFolioReport.aspx?Year=3/31/2012\%2012:00:00\%20AM } \\ \text { [4] } & \text { http://www.hdfcfund.com/NAVCorner/NAVHistory.aspx?ReportI=E31EBD9F-E113-409A-80F0-1974E07DAFCE } \\ \text { [5] } & \text { http://www.icicipruamc.com/NAVAndDividend/NAVHistory.aspx } \\ \text { [6] } & \text { http://www.utimf.com/fundperformance/pages/nav.aspx } \\ \text { [7] } & \text { http://www.licnomuramf.com/Mf_NAVHist.aspx?opt=5 }\end{array}$

\section{Journals:}

[1] Soongswang Amporn, Open-Ended Equity Mutual Funds, International Journal of Business and Social Science Vol. 2 No. 17.

[2] Vaidyanathan R., Capital Asset Pricing Model The Indian Context, The ICFAI Jornal of APPLIEDFINANCE, Vol 1 No. 2 (July

[3] Debasish Sathya Swaroop (2009), Investigating Performance of Equity-based Mutual Fund Schemes in Indian Scenario, KCA Journal of Business Management. VOL. 2, ISSUE 2.

\section{Reports:}

[1] SigmanKarl(2005), CapitalAssetPricingModel.

[2] Agrawal, Deepak, Measuring Performance of Indian Mutual Funds, Social Science Research Network.

[3] Harvey Campbell R. and Stephen Gray (1997), Asset pricing Models, Global Financial Management. 